〈総 説〉

\title{
社交不安症における心理的ストレッサーに対するコルチゾール反応 一メ夕分析による検討一
}

\author{
前田駿太 $^{1,2}$ 増田悠斗 $^{1}$ 佐藤友哉 $^{3}$ 嶋田洋徳 $^{4}$ \\ ${ }^{1}$ 早稲田大学大学院人間科学研究科 \\ 2 日本学術振興会特別研究員 \\ 3 新潟大学人文社会・教育科学系 \\ ${ }^{4}$ 早稲田大学人間科学学術院
}

\begin{abstract}
要約
本研究の目的は, 社交不安症に挍ける心理的ストレッサーに対するコルチゾール反応についてメ夕分 析を用いて検討することであった。文献検索の結果, 社交不安症の診断基準を満たす者と健常者の間 で心理的ストレッサーに対するコルチゾール反応を比較している9報の文献が抽出された（社交不安 症群： $N=265$ ；健常群： $N=199$ )。そして, ベースライン期，ストレス期（ストレス負荷後25分ま で）, 回復期（ストレス負荷後25分経過以降）の3つの時期それぞれに执いて, 社交不安症群と健常 群のコルチゾール值の差分值に基づく効果量を算出した。メ夕分析の結果，いずれの時期に扔いても 社交不安症群は健常群よりも高いコルチゾール值を示すことが明らかになった。このことから，社交 不安症においては直接的なストレッサーの呈示に対してのみならず, ストレッサー呈示前後の認知的 処理によってもコルチゾール反応が充進していることが示唆された。

キーワード：社交不安症，コルチゾール，メ夕分析
\end{abstract}

\section{【背景】}

他者からの否定的評価に対する恐れを主要な 特徵とする, 社交不安症においては, 社交場面 は重大なストレッサーとなりうるものである。 生体はストレッサーに対して, 認知, 情動, 生 理など様々な側面に扔ける反応を示すが，この うち社交不安症に拈けるストレッサーに対する 生理的反応として, 社交場面に曝露された際の 視床下部一下垂体一副腎系 (HPA系) の反応に 関する検討が多く行われてきた (e.g., Condren et al., 2002; Furlan et al., 2001)。HPA系はスト レッサーに対する主要な生理的反応経路の 1 つ であり, 社交不安症においては, 認知や行動と いった心理学的機能を調整する働きを担ってい ると考えられている（城月，2012）。そのため, 社交不安症の発症および維持に関する機序を包
括的に理解する上でHPA系の機能の変化に関 する研究は重要であると考えられる。

従来の研究に打いては，HPA系の最終生成 物であるコルチゾールを主な指標として, 社交 不安症に扮ける心理的ストレッサーに対する HPA系の反応に関する検討が行われてきた。 しかしながら, 社交不安症に扔ける心理的ス卜 レッサーに対するコルチゾール反応について, 従来の研究において一貫した知見が報告されて いるとはいいがたい。具体的には，健常者より も強い反応を報告している研究 (e.g., Condren et al., 2002)，健常者よりも弱い反応を報告し ている研究 (e.g., Shirotsuki et al., 2009), 健常 者との差がみられないとする研究 (e.g., Graver \&White, 2007）がそれぞれ存在しているのが 現状である。また，社交不安症における心理的 ストレッサーに対するコルチゾール反応に関す 
るレビューも複数なされてきたが, レビューと しても, 比較的一貫して反応の立進がみられる としているもの (Elnazer \& Baldwin, 2014) や, 反応性の克進を示す知見のみならず，健常者と 比較して反応性が低下している「鈍麻」を示す 知見も存在するとしているもの（城月，2012） が存在し, 統一的な見解は得られていない。し たがって,より精緻な手続きを用いて従来の研 究知見を整理する試みは有用であると考えられ る。

社交不安症における心理的ストレッサーに対 するコルチゾール反応に関して整理したこれま でのレビュー論文として, 前述の Elnazer \& Baldwin (2014) や城月 (2012) があるが, こ れらのレビューの手続きにおいては複数の問題 を指摘できると考えられる。まず，いずれのレ ビューにおいても包括的な文献検索が行われて いるとはいいがたい。たとえば, Elnazer \& Baldwin (2014) に扔いては, 文献の検索方法 として, データベースとしてPubMedを用いた 電子検索のみが用いられており, 臨床心理学領 域に扔ける知見は十分に網羅できていない可能 性がある。一方で, 城月（2012）に拈いては 臨床心理学領域における知見にも一定の言及が なされているものの, 文献検索の方法が明示さ れていないという問題が存在する。また，これ らの2報のレビューにおいては，コルチゾール 反応に影響を及ぼす可能性がある変数が十分に 考慮されていない。具体的には, 対象者の性別, 年齢層, 社交不安のスクリーニング方法などが 異なる対象者に関する研究知見が並列に論じら れているという問題がある。これらの問題を解 決するためには, より包括的な文献検索を行 い, かつ包含基準を明確に設けたうえで研究知 見を整理する必要があると考えられる。

これらの問題に加えて, 社交不安症における 心理的ストレッサーに対するコルチゾール反応 に関する研究知見は，1群あたり10名前後の小 さいサンプルに基づいて得られたものも少なく ない (e.g., Graver \& White, 2007)。このこと
をふまえると, 一部の研究において社交不安症 による群間差が報告されていないことは，この ようなサンプルサイズの小ささに起因する検出 力の低さによるものである可能性も否定できな い。したがって, 有意性検定の結果のみに基づ いて当該領域の研究知見を整理することは必ず しも適切ではないと考えられる。このような研 究動向がみられる領域においては, むしろ研究 知見を量的に統合するメ夕分析の手法が有効で あると考えられる。

さらに, 先行研究を整理するにあたっては, ストレッサーの呈示時点を基準とするコルチ ゾール值の経時的変化という観点も考慮すべき であると考えられる。ストレッサーに対する適 応という観点からは，ストレッサーの呈示に対 して適応的な生理的反応が開始され，ストレッ サーが消失した際に生理的反応が平常時の水準 まで回復することが重要視されている (McEwen, 1998)。一方で, これまでの研究に おいては, ベースラインとストレス負荷後のコ ルチゾールの変化量の最大值 $(\Delta \max$ 值) (e.g., Condren et al., 2002）やストレス負荷後の経過 時間を考慮しない「ストレス負荷後」を単位と した比較が多く行われてきた。すなわち、コル チゾール值は測定時点にかかわらず同等に捉え られており, 前述の経時的変化という観点は十 分に考慮されてこなかったと考えられる。この ような経時的変化という観点から心理的ス卜 レッサーに対するコルチゾール反応を整理した メタ分析として, Burke et al. (2005) が挙げら れるが，大うつ病患者に限定された検討であ り, 社交不安症患者を対象とした検討は見受け られない。

これらのことを踏まえ, 本研究においては社 交不安症に扔ける心理的ストレッサーに対する コルチゾール反応について, 研究内の測定時点 を考慮したメタ分析によって統合的に検討する ことを目的とした。 


\section{【方法】}

\section{1. 文献収集}

社交不安症におけるコルチゾール反応を検討 した文献を収集することを目的に文献収集を 行った。まず，英文文献の収集にあたって， PsyclNFO, PubMed, Scopusの3つのデータベー スを使用し，検索式として「(“social anxiety” OR “social phobia”) AND cortisol」を用いて 検索を行った。その結果, PsycINFOでは69報, PubMedでは 68 報, Scopusでは83 報の文献が 抽出された（2015年 7 月 4 日時点）。加えて, 邦文文献に関しては，CiNii，医中誌Webを使 用し，検索式として「(社交不安 OR社会不安) ANDコルチゾール」を用いて検索を行った。 その結果, CiNiiでは該当する文献はなく, 医 中誌Web で 1 報の文献が抽出された（2015年 7 月 4 日時点)。さらに, 不安症に㧍けるコルチ ゾール反応を扱った近年のレビュー論文 (Elnazer \& Baldwin, 2014; 城月，2012）加本 研究の目的に関連すると考えられる文献 9 報を 抽出した。加えて, 第 1 著者がハンドサーチを 行い，2 報の文献を追加した。以上の文献につ いて，データベース間で重複する文献を削除し て統合し，110報からなる文献リストを作成し た。

前述の手続きで得られた文献リストから，本 研究の目的と合致する文献を抽出した。本研究 における適格基準は，（a）社交不安症の診断基 準を満たす者と健常対照群の比較を行っている もの，(b) 大人（18歳以上）を対象としてい るもの，（c）身体疾患を合併している者を対象 としていないもの，(d) 心理的ストレッサー (他者の前で行う認知課題やスピーチ課題など, 他者が同席している社交場面に関連するス卜 レッサー）に対するコルチゾール反応性を検討 しているもの, (e) 査読つき学術誌に掲載され ている研究論文であるもの，をすべて満たすも のとした。具体的な文献選定の手続きとして, まず，第 1 著者が文献リス卜における文献の夕
イトル，キーワード，アブストラクトのレ ビューを行なった。そして（a）から（e）のい ずれかの基準を満たさないと判断した文献を除 外するスクリーニングを行い，16報の文献を 抽出した。次に, 詳細な適格性の評価のため, 抽出された 16 報の文献について第 2 , 第 3 著者 が独立に本文のレビューを行った。その結果, 評定者間の評定は完全に一致し $(\kappa=1.00), 10$ 報の文献が適格と判断された。文献抽出の全体 像はFigure 1 に示した。

その後，抽出された文献について，第1著者 が各研究の特徴を概観し, その特徴について コード化した。具体的なコード化のカテゴリと して，まず社交不安症以外の臨床的特徵として 「大うつ病性障害の合併の有無」，および「幼児 期の被虐待経験の有無」を設定した(いずれも， なし（報告なしを含む）：0，あり：1としてコー ド化)。また, 社交不安症の診断上特定される 「社交不安のサブタイプ」も設定した（報告な し: 0 , 非全般型 $: 1$, 全般型 $: 2$ としてコード 化)。さらに、コルチゾールの測定值に影響を 及ぼす可能性がある「コルチゾールの測定法」 を設定した（唾液：0，血液：1としてコード 化)。加えて，大うつ病を対象に同様のメ夕分 析を行った Burke et al. (2005) に基づき，「ス トレッサーの特徵」を設定した（認知課題の み：0，スピーチ課題を含む：1としてコード 化)。

\section{2. 効果量の算出}

対象となった文献において，文献の本文拈よ び図表から効果量の算出に必要なコルチゾール の平均值，および標準誤差（または標準偏差） を抽出した。值が図示されている研究において は，原子核反応デー夕研究開発センターが開発 したグラフ数值読取システム（GSYS2.4）を使 用し，值を小数第 2 位まで読み取った。なお， 効果量の算出に必要な平均值や標準誤差が記載 されていない 1 報の文献をこの段階で除外し， 最終的に9報の文献を効果量算出の対象とし 


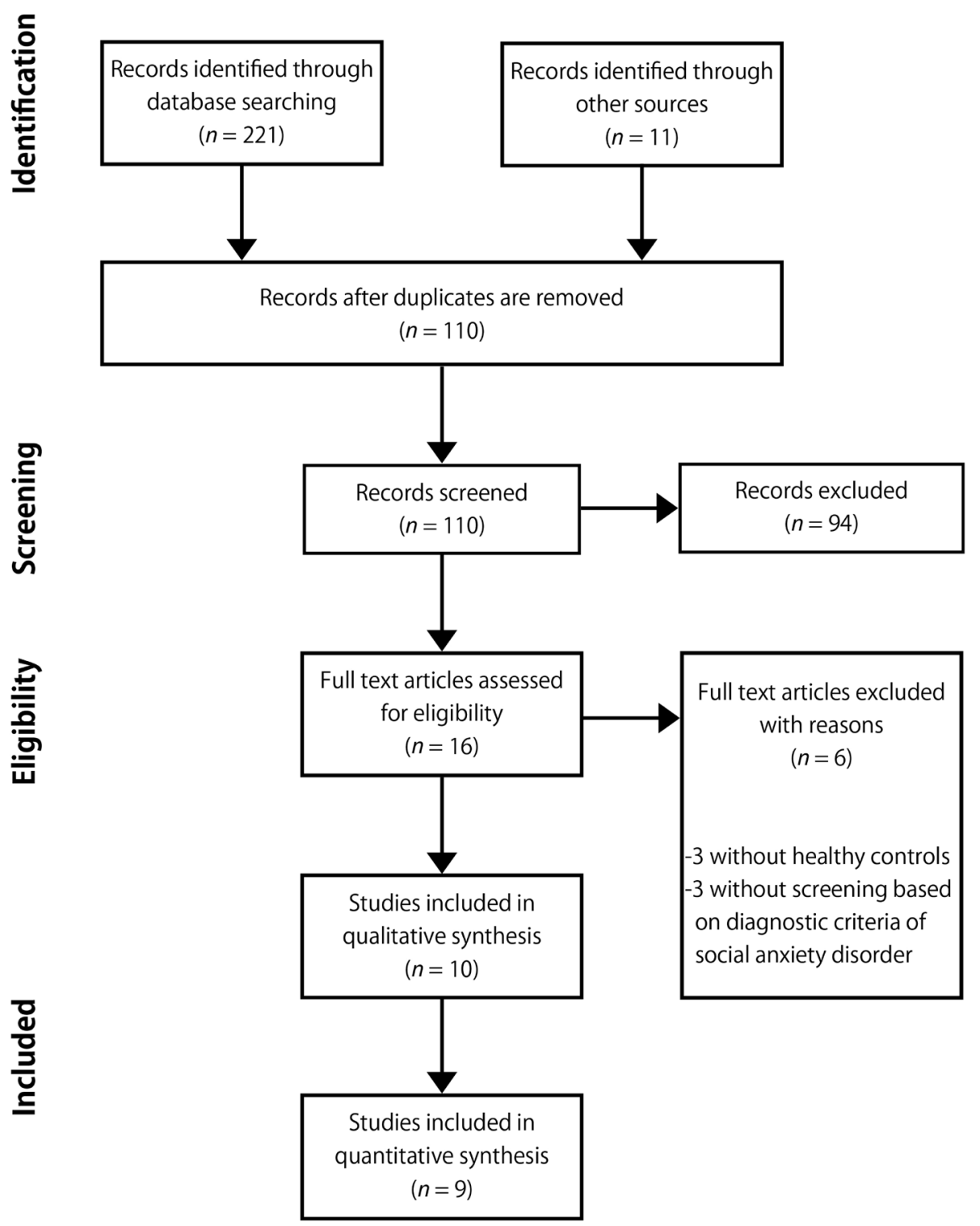

Figure 1. PRISMA flow chart of article retrieval and selection (based on Moher et al., 2009)

た。また，Klumbies et al.（2014）は唾液中， 血中それぞれのコルチゾール值を報告している ため, より欠測值が少なかった血中コルチゾー ル值を抽出した。

抽出した数值を使用して, 効果量として $d$ 值 の算出を行った。具体的な手続きとして, まず, 各研究内のすべての測定時点において, 社交不
安症群と健常群のコルチゾールの平均值差の $d$ 值を算出した。そして, ベースライン期, ス トレス期, 回復期の各時期を単位として, $d$ 值 の平均值を算出し, 当該研究におけるべースラ イン期, ストレス期, 回復期の効果量として使 用した。なお，Burke et al. (2005) の定義に基 づき, ベースライン期はストレッサー呈示以 
前, ストレス期は呈示後 25 分まで, 回復期は 呈示後25分以降として操作的に定義した。25 分がアンカーポイントとされているのは, 心理 的ストレッサーの呈示 20〜30 分後にコルチ ゾールは最大值をとるとされているためである (Kirschbaum \& Hellhammer, 1989)。

なお, 単一の研究内で臨床像の差異によるサ ブグループ別に結果が報告されている場合 （e.g., Yoon \& Joormann, 2012）は, サブグルー プ別の結果を独立した研究結果として扱い, 個 別に効果量を算出した。ただし、コルチゾール の反応性の高低によってサブグループを設けて いる研究（Furlan et al., 2001）に関しては, サ ブグループ別に効果量を算出すると研究間の統 計的異質性が過大評価されることが予想され た。この場合, 各サブグループにおける参加者 の臨床的特徵には質的な差異がないと判断し,

Borenstein et al. (2009) の方法を用いて群間の 平均值と標準誤差を統合して単一の効果量を算 出した。

\section{3. 統計的解析}

抽出した各研究の効果量をもとに, 変量効果 モデルを用いてベースライン期，ストレス期， 回復期それぞれに抄ける効果量を独立に算出し た。また, メ夕分析に含まれる研究の統計的異 質性について検討するために， $I^{2}$ 值を算出し た。統計的異質性が見受けられた場合にはコー ド化された研究の特徵, ストレッサー呈示開始 を起点とした経過時間, およびストレス期と回 復期においてはベースライン期のコルチゾール 值（Burke et al., 2005）を説明変数としたメタ 回帰分析を行うこととした。加えて, 公表バイ アスについて評価するために, ファンネルプ ロットの対称性の検定を行った。分析は $\mathrm{R}$ version 3.1.1 環境で metaforパッケージを用い て行った。

\section{【結果】}

\section{1. 抽出された研究の特徵}

本研究における分析の対象となった文献とそ の特徵を Table 1 に示した。対象者の総計は社 交不安症群 265 名, 健常群 199名であった。な お,コルチゾール值は日内変動の影響を受ける ため, 測定の時間帯を考慮する必要があるが, 実験の実施時間帯が明示されていなかった Klumbies et al. (2014) を除いてすべて測定は 午後に行われていた。また, 各研究の3つの測 定時期に扮ける，ストレッサー呈示開始を起点 とした経過時間の平均值は, ベースライン期で は-14.92分 $(S D=13.17)$ ，ストレス期では 23.87 分 $(S D=5.34)$ ，そして回復期では 53.44 分 $(S D=7.06)$ であった。

\section{2. ベースライン期における反応性の差異}

ベースライン期の社交不安症群と健常群のコ ルチゾール值の差の効果量は $d=.23$ でった (95\% CI: $[.05, .40], p=.01$; Figure 2)。すなわ ち, ベースライン期において社交不安症群は健 常群よりも高いコルチゾール值を示した。ま た, $I^{2}$ 值は低值 $\left(I^{2}=0.00 \%\right)$ であり, 統計的 異質性は小さいと判断された。

\section{3. ストレス期における反応性の差異}

ストレス期のコルチゾール值の差の効果量は $d=.24$ であった（95\% CI: [.01,.46], $p=.04$; Figure 2)。すなわち，ストレス期において社 交不安症群は健常群より高いコルチゾール值を 示した。また, $I^{2}$ 值は低值 $\left(I^{2}=29.64 \%\right)$ であ り, 統計的異質性は小さいと判断された。

\section{4. 回復期における反応性の差異}

回復期におけるコルチゾール值の差の効果量 は $d=.34$ であった $(95 \%$ CI: $[.05, .63], p=.02$; Figure 2)。すなわち, 回復期において社交不 安症群は健常群よりも高いコルチゾール值を示 した。しかしながら, 回復期においては中程度 
前田ほか：社交不安症におけるコルチゾール反応のメ夕分析

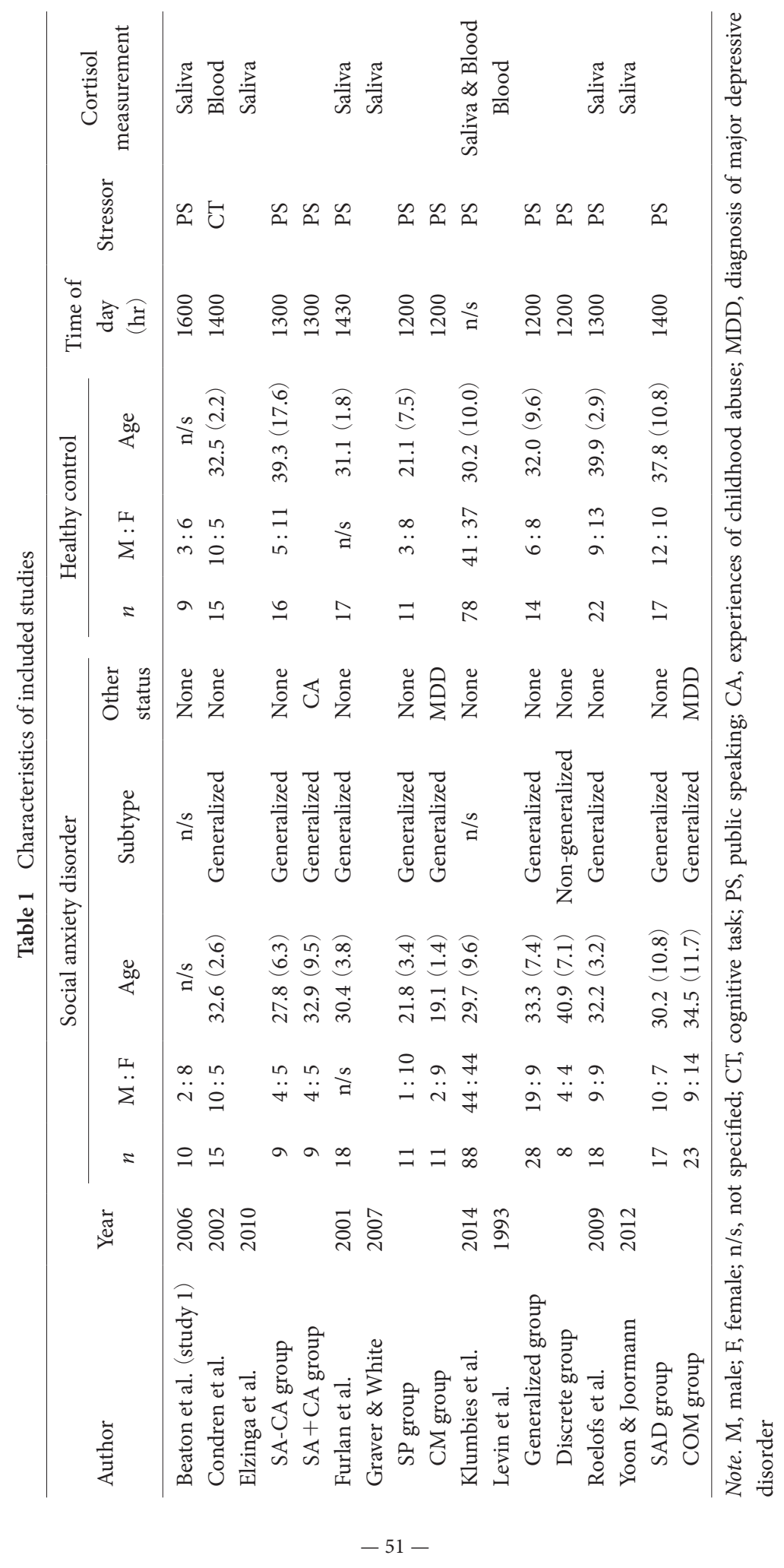


Bas eline period (befere stress or onset)

Author, Year, Subgroup

Cohen's $d[95 \% \mathrm{Cl}]$

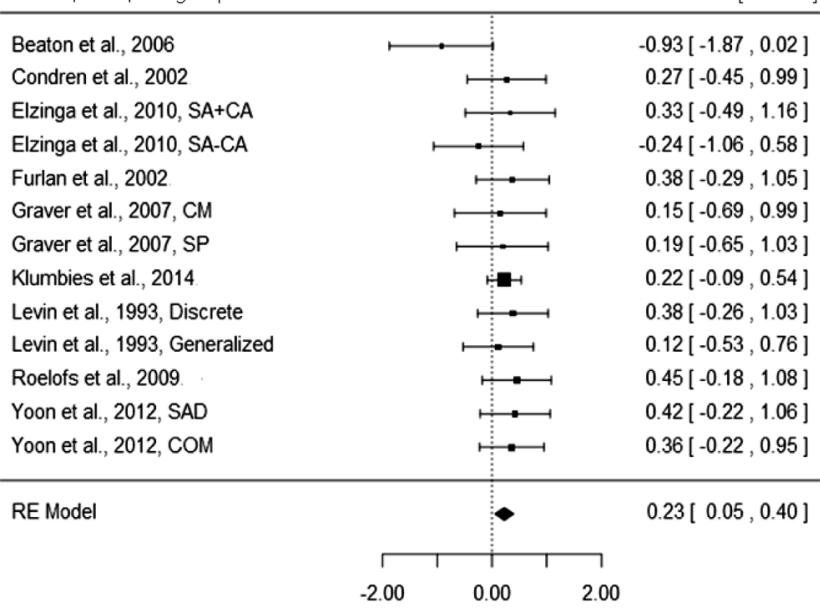

Stress period (stress or onset up to $\mathbf{2 5}$ minutes after stressor offs et)

A.uthor, Year, Subgroup

Cohen's $d[95 \% \mathrm{Cl}]$

\begin{tabular}{ll}
\hline Beaton et al., 2006 \\
Condren et al., 2002 \\
Elzinga et al., 2010, SA+CA \\
Elzinga et al., 2010, SA-CA \\
Furlan et al., 2002 \\
Graver et al., 2007, CM \\
Graver et al., 2007, SP \\
Klumbies et al., 2014 \\
Levin et al., 1993, Discrete \\
Levin et al., 1993, Generalized \\
Roelofs et al., 2009 \\
Yoon et al., 2012, SAD \\
Yoon et al., 2012, COM
\end{tabular}

Recovery period (more than $\mathbf{2 5}$ minutes after stre ss or offs et)

Author, Year, Subgroup

Cohen's $d[95 \% \mathrm{Cl}]$

Condren et al., 2002
Elzinga et al., 2010, SA+CA
Elzinga et al., 2010, SA-CA
Furlan et al., 2002
Klumbies et al., 2014
Roelofs et al., 2009
Yoon et al., 2012, SAD
Yoon et al., 2012, COM

Figure 2. Forest plots in each time period 


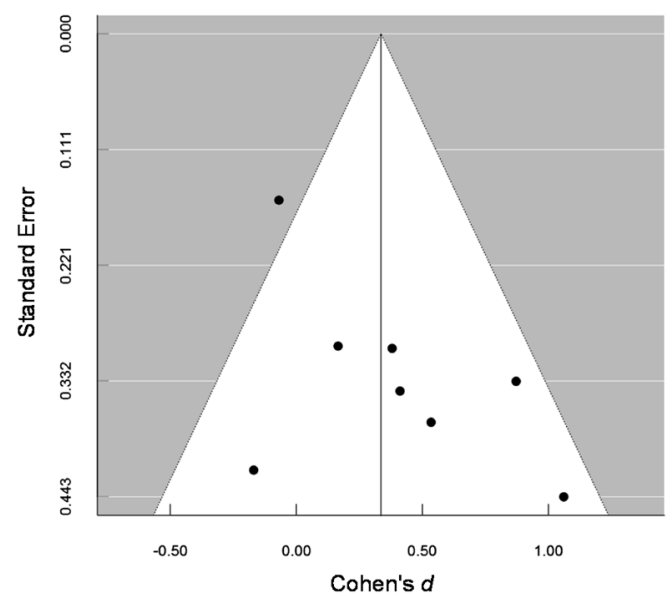

Figure 3. Funnel plot in the recovery period

の統計的異質性 $\left(I^{2}=44.05 \%\right)$ がみられた。 そこで, 研究間の異質性を説明することを目的 としたメタ回帰分析を行った。その結果, 社交 不安のサブタイプ $\left(Q(1)=6.20, p=.01, R^{2}=\right.$ 99.99）によって異質性は有意に説明され，全 般性サブタイプの者のみを対象としている研究 において効果量が大きくなる傾向にあった。 また， $5 \%$ 水準で有意ではないものの, ベース ライン期のコルチゾール值 $(Q(1)=3.13$, $p=.08, R^{2}=49.97 ） に よ っ て$ 異質性の一部が 説明される傾向が見受けられた。ストレッサー 呈示開始からの経過時間を含むその他の変数 で異質性を有意に説明するものはなかった $(Q s<2.41, p s>.12)$ 。

\section{5. 公表バイアスの検討}

公表バイアスについて検討するために，ファ ンネルプロットの対称性の検定を行った。その 結果, ベースライン期とストレス期においては 対称性の仮定は棄却されなかった（それぞれ， $z=-.89, p=.37 ; z=-.12, p=.90)$ 。一方で, 回 復期のファンネルプロットにおいては対称性の 仮定は棄却された $(z=2.51, p=.01)$ (Figure 3)。

\section{【考察】}

本研究の目的は, 社交不安症患者と健常者の
心理的ストレッサーに対するコルチゾール反応 の差異についてメ夕分析によって検討すること であった。ベースライン期，ストレス期，回復 期のそれぞれにおける分析の結果, 社交不安症 患者はいずれの時期においても健常者よりも高 いコルチゾール值を示すことが明らかになっ た。

これまでの研究においては, 社交不安症にお けるコルチゾール反応性については一貫した知 見が得られてきたとはいいがたく, 実際に回復 期においては研究間に統計的異質性が認められ た。その一方で, ベースライン期とストレス期 における研究間の統計的異質性は低い水準に あった。このような異質性の低さの一因とし て, 社交不安症の診断基準を満たす大人を対象 とした研究のみを包含したことが考えられる。 本研究の目的に概ね合致するが包含されなかっ た研究として, たとえば, Shirotsuki et al. (2009) は他者からの否定的な評価に対する恐れに関す る主観評価に基づくスクリーニングを行い，高 社交不安者において低社交不安者よりも低いコ ルチゾール反応がみられることを報告してい る。しかしながら, この方法では, 社交場面か らの回避をはじめとした生活上の支障をきたす 症状の有無などにおいて必ずしも診断基準を満 たす者と等質な者を抽出できるとはいいがた く, このような臨床像の差異が反応性に影響し ている可能性がある。

ストレス期のコルチゾール反応の忘進につい ては, 社交不安症患者にとって社交場面がより 顕著なストレッサーとなるために反応の立進が みられると理解できると考えられる。一方で, ベースライン期と回復期においては, ストレッ サーそのものは呈示されていないため, ストレ ス期と同様に理解することは困難であると考え られる。これについての解釈の 1 つとして, ベースライン期と回復期の反応性の立進の背景 には社交不安症に特徵的な認知処理が存在して いることが考えられる。たとえば，回復期のコ ルチゾール反応の充進は, 心理的ストレッサー 
消失後の回顧的な認知的処理 (post-event processing; Clark \& Wells, 1995）によるもので ある可能性がある。実際に, 心理的ストレッ サー呈示後にストレッサーについて回顧的に考 え続けると高いコルチゾール值が持続するとい う知見が存在する (e.g., Zoccola et al., 2008)。 ただし、メタ回帰分析の結果から, 回復期のコ ルチゾール值は全般性サブタイプを有する者や ベースライン期のコルチゾール值が高い者にお いて高くなる傾向にあることが示唆されるた め, 臨床像による差異にも留意すべきであると 考えられる。

ベースライン期の結果を考察するにあたって は, 本研究における「ベースライン期」のコル チゾール值は，いわゆる「安静期」における基 礎値を表しているわけではなく, 実験室場面に おいて心理的ストレッサーの呈示を予告された 状態における值であることに留意すべきである と考えられる。実際に, 本研究においては検討 に含めていないが, 顕在的なストレッサーを課 さない, 日常生活の安静期におけるコルチゾー ルの基礎値については社交不安症患者と健常者 の間に差がみられないことが一貫して報告され ている (e.g., Potts et al., 1991)。このことを踏 まえると, 社交不安症患者がベースライン期に おいて示すコルチゾール值の高さは全般的な過 覚醒状態によるものであるというよりは, 心理 的ストレッサーに対する「予期」のような認知 的処理によって生じている可能性がある。たと えば, Clark \& Wells (1995) は, 社交不安症患 者は社交場面に参与する前にその場面について 詳細に考える (anticipatory processing) こと を指摘している。しかしながら, 実際にこのよ うな処理がコルチゾール反応に寄与しているか 否かを標的とした検討はいまだなされておら ず，今後検討を行う必要があると考えられる。 なお, 本研究の限界として, 回復期の結果に おいて検出された公表バイアスが挙げられる。 ただし、ファンネルプロットの視察からは, こ の公表バイアスが単に効果量が小さい研究の未
発表によるものと結論づけることは困難であ り, 効果量の大きい研究, その中でも特に大規 模な研究が実施されていないことも原因として 想定される。心理的ストレッサーに対するコル チゾール反応の測定においては, 曜日や実施時 間带による反応性の変動を考慮する必要性から の実施日程の制約などにより, 大規模なデー夕 を収集することは容易ではないと考えられる。 小規模なデータの収集しか行われてこなかった 研究領域においてこそ, メ夕分析の手法は有効 であるといえるが, Klumbies et al. (2014) の ような大規模なサンプルを確保した研究におい て本研究の知見が再現されれば社交不安症にお けるコルチゾール反応性に関する知見はより強 固なものとなると考えられる。

また, 本研究では, ストレッサー呈示後 25 分以降を回復期として操作的に定義したが，実 際にはストレッサー呈示後にコルチゾール值が 最大值をとるまでの経過時間には, 研究間で 20〜30分というばらつきが報告されている (Kirschbaum \& Hellhammer, 1989)。したがっ て,「コルチゾールの最大值からの值の低減」 を検討するという観点において, 本研究の回復 期の定義には限界があると考えられる。今後, 回復期に扮ける結果を裏づけるためには, これ までの研究ではほとんど見受けられない,コル チゾールの最大值からの值の低減そのものを直 接的に指標とした検討が有用であると考えられ る。

このような限界は見受けられるものの, 本研 究に含まれた研究間の統計的異質性は比較的低 い水準にとどまっており，本研究の知見は一定 の信頼性を有するものであると考えられる。本 研究の結果から示唆される, 社交不安症に招け る心理的ストレッサーに対するコルチゾール反 応性の忘進をふまえ, 今後の研究においてはこ のコルチゾール反応性の充進が社交不安症の維 持, 悪化にどのように寄与しているのかを検討 することが有意義であると考えられる。たとえ ば, 抑うつに関する研究領域では, ストレッ 
サーに対するコルチゾール反応性が強い者は抑

うつ関連刺激に対する選択的注意を示しやすく なることが明らかにされている（Tsumura \& Shimada, 2012)。社交不安症における同様の 知見として, van Peer et al. (2009) は, ヒド ロコルチゾンを投与された社交不安症患者が怒 り表情刺激の選択的処理を示しやすくなること を報告している。この研究は, コルチゾール反 応が社交不安症における不適応的な情報処理を 促進させることを示す知見であり，ひいてはコ ルチゾール反応が社交不安症状の維持に寄与す ることを示唆する知見である。このように、コ ルチゾール反応をストレス反応のバイオマー カーとしてみなすのみならず，ストレス反応と して生じたコルチゾール反応が後の不適応的な 情報処理を生じさせるといった，コルチゾール 反応と情報処理の相互作用が社交不安症状の維 持に及ぼす影響についてさらなる検討を行うこ とが望ましいと考えられる。

\section{【文献】}

Beaton, E. A., Schmidt, L. A., Ashbaugh, A. R., Santesso, D. L., Antony, M. M., McCabe, R. E., Segalowitz, S. J., \& Schulkin, J. (2006). Low salivary cortisol levels among socially anxious young adults: Preliminary evidence from a selected and a non-selected sample. Personality and Individual Differences, 41, 1217-1228.

Borenstein, M., Hedges, L. V., Higgins, J. P. T., \& Rothstern, H. R. (2009). Introduction to meta-analysis. West Sussex: Wiley.

Burke, H. M., Davis, M. C., Otte, C., \& Mohr, D. C. (2005). Depression and cortisol responses to psychological stress: A meta-analysis. Psychoneuroendocrinology, 30, 846-856.

Clark, D. M., \& Wells, A. (1995). A cognitive model of social phobia. In R. G. Heimberg, M. R. Liebowitz, D. A. Hope \& F. R. Schneier (Eds.), Social phobia: Diagnosis, assessment, and treatment. New York: Guilford Press.

Condren, R. M., Neill, A. O., Ryan, M. C. M., \& Barrett, P. (2002). HPA axis response to a psychological stressor in generalized social phobia.
Psychoneuroendocrinology, 27, 693-703.

Elnazer, H. Y., \& Baldwin, D. S. (2014). Investigation of cortisol levels in patients with anxiety disorders: A structured review. Current Topics of Behavioral Neuroscience, 18, 191-216.

Elzinga, B. M., Spinhoven, P., Berretty, E., de Jong, P., \& Roelofs, K. (2010). The role of childhood abuse in HPA-axis reactivity in social anxiety disorder: A pilot study. Biological Psychology, 83, 1-6.

Furlan, P. M., DeMartinis, N., Schweizer, E., Rickels, K., \& Lucki, I. (2001). Abnormal salivary cortisol levels in social phobic patients in response to acute psychological but not physical stress. Biological Psychiatry, 50, 254-259.

Graver, C. J., \& White, P. M. (2007). Neuropsychological effects of stress on social phobia with and without comorbid depression. Behaviour Research and Therapy, 45, 1193-1206.

Kirschbaum, C., \& Hellhammer, D. H. (1989). Salivary cortisol in psychological research: An overview. Neuropsychobiology, 22, 150-169.

Klumbies, E., Braeuer, D., Hoyer, J., \& Kirschbaum, C. (2014). The reaction to social stress in social phobia: Discordance between physiological and subjective parameters. PLoS ONE, 9, e105670.

Levin, A. P., Saoud, J. B., Strauman, T., Gorman, J. M., Fyer, A. J., Crawford, R., \& Liebowitz, M. R. (1993). Responses of "generalized" and "discrete" social phobics during public speaking. Journal of Anxiety Disorders, 7, 207-221.

McEwen, B. S. (1998). Protective and damaging effects of mediators of stress. The New England Journal of Medicine, 338, 171-179.

Moher, D., Liberati, A., Tetzlaff, J., Altman, D. G., \& The PRISMA Group. (2009). Preferred reporting items for systematic reviews and meta-analyses: The PRISMA statement. PLoS Medicine, 6, e1000097.

Potts, N. L., Davidson, J. R., Krishnan, K. R., Doraiswamy, P. M, \& Ritchie, J. C. (1991). Levels of urinary free cortisol in social phobia. Journal of Clinical Psychiatry, 52, 41-42.

Roelofs, K., van Peer, J., Berretty, E., de Jong, P., Spinhoven, P., \& Elzinga, B. M. (2009). Hypothalamus-Pituitary-Adrenal axis hyperresponsiveness is associated with increased social avoidance behavior in social phobia. Biological Psychiatry, 65, 
336-343.

城月健太郎 (2012). 社交不安障害における認知行動 モデルとHPA系 精神科, 21, 574-577.

Shirotsuki, K., Izawa, S., Sugaya, N., Yamada, K. C., Ogawa, N., Ouchi, Y., Nagano, Y. \& Nomura, S. (2009). Salivary cortisol and DHEA reactivity to psychosocial stress in socially anxious males. International Journal of Psychophysiology, 72, 198-203.

Tsumura, H., \& Shimada, H. (2012). Acutely elevated cortisol in response to stressor is associated with attentional bias toward depression-related stimuli but is not associated with attentional function. Applied Psychophysiology and Biofeedback, 37, 19-29. van Peer, J. M., Spinhoven, P., Dijk, J. G. Van, \& Roelofs, K. (2009). Cortisol-induced enhancement of emotional face processing in social phobia depends on symptom severity and motivational context. $\mathrm{Bi}$ ological Psychology, 81, 123-130.

Yoon, K. L., \& Joormann, J. (2012). Stress reactivity in social anxiety disorder with and without comorbid depression. Journal of Abnormal Psychology, 121, 250-255.

Zoccola, P. M., Dickerson, S. S., \& Zaldivar, F. P. (2008). Rumination and cortisol responses to laboratory stressors. Psychosomatic Medicine, 70, 661-667. 


\title{
Cortisol Responses to Psychological Stressors in Social Anxiety Disorder: A Meta-Analysis
}

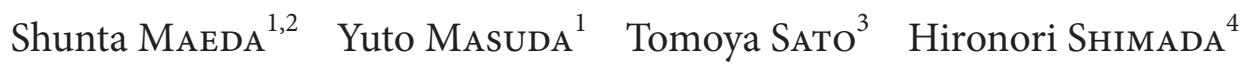 \\ ${ }^{1}$ Graduate School of Human Sciences, Waseda University \\ ${ }^{2}$ Research Fellow of the Japan Society for the Promotion of Science \\ ${ }^{3}$ Institute of Humanities, Social Sciences and Education, Niigata University \\ ${ }^{4}$ Faculty of Human Sciences, Waseda University
}

\begin{abstract}
The purpose of this meta-analysis is to examine the association between social anxiety disorder and cortisol response to psychological stressors. A total of 9 studies comparing individuals diagnosed with social anxiety disorder (SA: $N=265)$ and healthy controls (HC: $N=199)$ were included. Effect sizes were calculated and averaged across baseline (before stressor onset), stress (stressor onset up to $25 \mathrm{~min}$ after stressor offset), and recovery (more than $25 \mathrm{~min}$ after stressor offset) periods. Overall, SA individuals exhibited higher cortisol levels at all time periods. This result indicates that SA individuals exhibit exaggerated cortisol response not only in the face of social stressors, but also through pre and post-stress cognitive processing.
\end{abstract}

Key Words: social anxiety disorder, cortisol, meta-analysis 